\title{
Transforming Growth Factor- $\beta$ Activity in Sheep Lung Lymph during the Development of Pulmonary Hypertension
}

\author{
Elizabeth A. Perkett, ${ }^{\star \|}$ Russette M. Lyons, ${ }^{\ddagger}$ Harold L. Moses, ${ }^{\ddagger}$ Kenneth L. Brigham, ${ }^{\star}$ and Barbara Meyrick ${ }^{\star s}$ \\ ${ }^{*}$ Departments of Medicine, ${ }^{\ddagger}$ Cell Biology, ${ }^{\S}$ Pathology, and $"$ Pediatrics, Center for Lung Research, \\ Vanderbilt University School of Medicine, Nashville, Tennessee 37232
}

\begin{abstract}
Chronic pulmonary hypertension is associated with extensive structural remodeling of the pulmonary arterial bed. The structural changes in the arterial walls include increased production of extracellular matrix components and smooth muscle cell hypertrophy, changes that have been similarly induced by transforming growth factor- $\beta$ (TGF- $\beta$ ) in culture. In the present study, experiments were performed to determine whether TGF- $\beta$ is present in sheep lung lymph, and whether TGF- $\beta$ levels were altered in an animal model of chronic pulmonary hypertension induced by continuous air embolization. Several standard biological assays for TGF- $\beta$ activity were used for these determinations including soft agar assays, inhibition of epithelial cell proliferation, and a TGF- $\beta$-specific radioreceptor assay. In each case, control lung lymph contained high concentrations of TGF- $\beta(100 \mathrm{ng} / \mathrm{ml})$ which required transient acidification for detection. Samples of lung lymph from hypertensive sheep showed a transient and early two- to threefold increase in concentrations of latent TGF- $\beta$. This activity could be partially blocked by TGF- $\beta$ antibodies. These studies indicate that sheep lung lymph contains TGF- $\beta$ and that the level of TGF- $\beta$ increases early during the development of pulmonary hypertension. Thus, TGF- $\beta$ may contribute to the development of the structural changes in the pulmonary arteries that occur during the onset of chronic pulmonary hypertension. (J. Clin. Invest. 1990. 86:1459-1464.) Key words: smooth muscle cells • pulmonary arteries
\end{abstract}

\section{Introduction}

Transforming growth factor- $\beta$ (TGF- $\beta)^{1}$ was originally defined by its ability to transform fibroblasts in culture $(1,2)$, however, numerous and diverse biological effects have now been reported (3). For example, TGF- $\beta$ stimulates the production of extracellular matrix components and protease inhibitors but decreases the production of proteases such that the overall effect is an increase in synthesis and deposition of extracellular matrix components (4-8). TGF- $\beta$ also stimulates elastin pro-

Address reprint requests to Dr. Elizabeth Perkett, Center for Lung Research, B1308 MCN, Vanderbilt Medical Center, Nashville, TN 37232.

Received for publication 25 October 1989 and in revised form 30 May 1990.

1. Abbreviations used in this paper: FBS, fetal bovine serum; MK, murine keratinocytes; TGF- $\beta$, transforming growth factor- $\beta$.

J. Clin. Invest.

(c) The American Society for Clinical Investigation, Inc.

0021-9738/90/11/1459/06 \$2.00

Volume 86, November 1990, 1459-1464 duction in cultured vascular smooth muscle cells (9), hypertrophy of smooth muscle cells (10), and depending on the culture conditions, smooth muscle cell proliferation can be stimulated or inhibited (11).

TGF- $\beta$ has been found to be ubiquitous; it has been detected in a variety of cultured cells, normal and neoplastic tissues (12), and serum (13). Platelets are one of the richest sources of TGF- $\beta$ (14). TGF- $\beta$ is released from cells and platelets in a latent, biologically inactive form that can be activated by extremes of $\mathrm{pH}(15)$, although a more physiological mechanism of activation has been proposed to involve proteases (16). It is likely that activation of latent TGF- $\beta$ plays an important role in the regulation of its action.

Chronic pulmonary hypertension often occurs as a secondary complication of many pulmonary disorders such as bronchopulmonary dysplasia, cystic fibrosis, chronic bronchitis, and emphysema. In some cases the hypertension becomes the predominant problem leading to death. Currently no therapy is available for the reversal of severe chronic pulmonary hypertension with the exception of heart or lung transplant. The irreversible disease is thought to result from extensive structural remodeling of the pulmonary arteries. Pathological evaluation of lung tissue from both human disease and animal models has defined a spectrum of characteristic changes that occur in the pulmonary arterial circulation. These changes include increased medial and adventitial thickness, appearance of muscle in normally nonmuscular arterial walls, and reduction in peripheral arterial volume (17). Since increased production of extracellular matrix and smooth muscle hypertrophy are features of the wall of hypertensive pulmonary arteries, and TGF- $\beta$ has been shown to induce similar changes in vitro, it is possible that TGF- $\beta$ contributes to the development of this disease.

TGF- $\beta$ has been shown to be present in human lung lavage fluid (18), but this fluid may not be representative of findings in lung interstitium and vascular walls. In sheep, interstitial fluid can be collected as it exits the lung from the caudal mediastinal lymph node. Biochemical markers of lung damage such as increased protein flux (19), increased prostanoid release (20), and free radical production (21) have been successfully measured in lung lymph. TGF- $\beta$ has not been measured in lung lymph.

This study uses control sheep to examine whether TGF- $\beta$ can be detected in lung lymph. The study also uses a model of chronic pulmonary hypertension in which sheep receive continuous air embolization (22) to assess whether levels of TGF- $\beta$ are altered during the development of this disease. The data indicate that latent TGF- $\beta$ is a normal constituent of lung lymph and that its levels increase early during the onset of pulmonary hypertension. TGF- $\beta$ may be linked to the development of the structural changes of chronic pulmonary hypertension. 


\section{Methods}

\section{Sheep model}

Chronically instrumented sheep were prepared as previously described (23). Briefly, bilateral thoracotomies were performed under general anesthesia for cannulation of the efferent duct of the caudal mediastinal lymph node and for placement of catheters in the left atrium and pulmonary artery. Catheters were also placed in the jugular vein and carotid artery. The animals recovered for at least $7 \mathrm{~d}$ before beginning experiments. Control animals underwent identical surgery and monitoring but no air embolization.

Continuous air embolization was administered as previously described (22). After baseline physiological measurements, air was infused into the pulmonary arterial circulation through the proximal port of a Swan Ganz catheter at a rate sufficient to cause a two- to threefold increase in pulmonary vascular resistance (baseline $=3.7$ Woods units; air embolization $=8.4$ ). This elevation in pulmonary vascular resistance is associated with a 1.5 -fold increase in mean pulmonary artery pressure (baseline $=19 \mathrm{~cm} \mathrm{H}_{2} \mathrm{O}$; air embolization $=35$ ). The animals were killed with an overdose of pentothal after $12 \mathrm{~d}$ of embolization.

Lung lymph was collected over a 30-min period and the flow rate recorded. Heparin ( $1 \mathrm{U} / \mathrm{ml}$ of lymph) was added to each sample. Baseline lung lymph flow averaged $4 \mathrm{ml} / \mathrm{h}$ and during air embolization it increased three- to fourfold as previously described (22). Lung lymph protein clearance was increased threefold over baseline throughout air embolization (baseline $=0.8 \mathrm{ml} / 15 \mathrm{~min}$; air embolization $=2.5$ ). . Lung lymph was centrifuged and the supernatant was frozen at $-70^{\circ} \mathrm{C}$. Samples were obtained from 6 control sheep between 7 and $21 \mathrm{~d}$ after the surgery and from 6 sheep during the $12 \mathrm{~d}$ of continuous air embolization.

\section{$T G F-\beta$ bioassays}

The presence of TGF- $\beta$ was detected in control lung lymph by its ability to stimulate fibroblast (AKR-2B, clone 84A) colony formation in soft agar and to inhibit proliferation of murine keratinocytes (MK). Lung lymph was assayed for TGF- $\beta$ activity in both acid treated and untreated samples. To activate latent TGF- $\beta$ an aliquot of each sample, diluted with binding buffer $(1: 10)$ to prevent precipitation of proteins, was acidified to a pH $<2.0$ with $12 \mathrm{~N} \mathrm{HCl}$. After $1 \mathrm{~h}$, the $\mathrm{pH}$ was adjusted to 7.4 with $10 \mathrm{~N} \mathrm{NaOH}$.

Soft agar assay. Lung lymph was evaluated for its ability to stimulate the growth of AKR-2B (clone 84A) cells in soft agar using previously described methods $(1,13)$. Base layers of $0.8 \%$ agar in McCoy's 5 a medium with $10 \%$ fetal bovine serum (FBS) were poured into 35-mm culture dishes. Lymph samples were added to the upper layer which contained $7.5 \times 10^{3}$ cells in $0.4 \%$ agar in McCoy's 5a medium with $10 \%$ FBS. Using an Ominicon Facs III image analyzer (Bausch \& Lomb, Inc., Rochester, NY) the number of colonies $>50 \mu \mathrm{m}$ in diameter that developed after 7-10 d were quantitated. Assays were performed in triplicate on samples from three control sheep.

MK inhibition assay. Mouse skin keratinocytes, a continuous epithelial cell line (24), are inhibited by picomolar concentrations of TGF- $\beta$ (25) and can be used for rapid and sensitive estimates of the presence of TGF- $\beta$-like activity from a variety of sources. The effect of lung lymph on incorporation of thymidine by MK cells was determined using a previously described method (25). Rapidly growing BALB/MK cells were placed in 24-well tissue culture plates $(40,000$ cells/well) in minimal essential medium containing $0.05 \mathrm{mM}$ calcium and supplemented with $8 \%$ dialyzed FBS and epidermal growth factor $(4 \mathrm{ng} / \mathrm{ml})$. Media was removed after $24 \mathrm{~h}$ and fresh media containing lymph samples were added. After $24 \mathrm{~h}$ incubation, $\left[{ }^{3} \mathrm{H}\right]$ thymidine $(2.5$ $\mu \mathrm{Ci} /$ well) was added to measure DNA synthesis. $2 \mathrm{~h}$ later, the cells were rinsed three times with ice-cold $10 \%$ trichloroacetic acid, air dried, and the DNA was extracted with $0.2 \mathrm{~N} \mathrm{NaOH}$. Radioactivity of each sample was counted with a scintillation counter. Samples from four sheep were assayed in triplicate.
Antibody neutralization. To block TGF- $\beta$ activity, lung lymph samples were incubated with polyclonal antibodies to TGF- $\beta$. AntiTGF- $\beta$ antibodies were prepared as previously described (26). Lung lymph samples were incubated at $4^{\circ} \mathrm{C}$ overnight with 10 or $100 \mu \mathrm{g} / \mathrm{ml}$ of anti-TGF- $\beta$ IgG or nonimmune rabbit IgG (Dako Corp., Santa Barbara, CA). The samples were then tested in the MK inhibition assay as described above.

\section{Radioreceptor assay for $T G F-\beta$}

A competitive radioreceptor assay was used to detect and quantitate TGF- $\beta$ in lung lymph from control and air embolized animals. This assay is specific and not influenced by the presence of other growth factors present in lung lymph.

Lung lymph samples were diluted 10-fold with binding buffer (128 $\mathrm{mM} \mathrm{NaCl}, 5 \mathrm{mM} \mathrm{KCl}, 5 \mathrm{mM} \mathrm{MgSO}_{4}, 1.2 \mathrm{mM} \mathrm{CaCl}_{2}, 50 \mathrm{mM}$ Hepes, $2 \mathrm{mg} / \mathrm{ml}$ bovine serum albumin). Latent TGF- $\beta$ was activated in an aliquot from each sample by transient acidification. The receptor assay was performed essentially as previously described $(27,28)$. Confluent AKR-2B (clone 84A) cells in 6-well tissue culture plates were incubated for $1 \mathrm{~h}$ with binding buffer. The cells were then incubated for $2 \mathrm{~h}$ at $22^{\circ} \mathrm{C}$ with binding buffer containing lymph samples and $0.25 \mathrm{ng}$ of ${ }^{125}$ I-labeled TGF- $\beta$ in a total volume of $1 \mathrm{ml} /$ well. Nonspecific binding was determined by the addition of $30 \mathrm{ng} / \mathrm{ml}$ of porcine TGF- $\beta$ (Research and Diagnostic Systems, Inc. Minneapolis, MN). Results are presented as percent inhibition of binding after correction for nonspecific binding. Controls and experimental samples were assayed in triplicate.

A standard curve was constructed using porcine platelet-derived TGF- $\beta$ and showed that $1 \mathrm{ng} / \mathrm{ml}$ of TGF- $\beta$ resulted in $50 \%$ inhibition. The concentration of TGF- $\beta$ in lung lymph was calculated by assuming that the volume of lymph resulting in $50 \%$ inhibition contained 1 $\mathrm{ng}$ of TGF- $\beta$.

\section{Results}

\section{Control lung lymph}

Soft agar assay. Sheep lung lymph stimulated fibroblast colony formation in soft agar (Fig. 1). Untreated lymph (30 $\mu \mathrm{l})$ resulted in a $50 \%$ increase in colony formation compared with control. However, after transient acidification of the lymph, the same volume ( $30 \mu \mathrm{l})$ of lung lymph caused a $500 \%$ increase in the number of colonies formed compared with control, suggesting that latent TGF- $\beta$ present in lung lymph had been activated. Small volumes of activated lymph $(1$ and $3 \mu \mathrm{l})$ appeared to inhibit colony formation, suggesting the presence of



Figure 1. AKR-2B cell colony formation in soft agar was markedly stimulated by $30 \mu \mathrm{l}$ of acid activated lymph. $30 \mu \mathrm{l}$ of untreated lymph caused a slight stimulation. Results are from triplicate wells for each sample. Control results (cells cultured in media alone) are shown in the open bar. $3 \mathrm{ng}$ of TGF- $\beta$ resulted in 1,300 colonies. 
other factors present in lung lymph that may inhibit the growth of AKR-2B cells in soft agar (no lymph $=82$ colonies; $1 \mu \mathrm{l}=20 ; 3 \mu \mathrm{l}=31$ ).

MK inhibition assay. Lung lymph inhibited the proliferation of MK cells providing additional evidence that TGF- $\beta$ is present in this fluid (Fig. 2). A $30 \%$ decrease in $\left[{ }^{3} \mathrm{H}\right]$ thymidine incorporation was evident when untreated lung lymph $(60 \mu \mathrm{l})$ was assayed as compared with control cultures. After acid activation, lung lymph $(60 \mu \mathrm{l})$ resulted in almost complete inhibition of $\left[{ }^{3} \mathrm{H}\right]$ thymidine incorporation. Smaller volumes of acid activated or untreated lung lymph $(20 \mu \mathrm{l})$ were also assayed for the ability to inhibit DNA synthesis of MK cells. This volume of untreated lung lymph has very little effect $(93 \%$ of control), whereas acid-treated lymph caused a significant inhibition of $\left[{ }^{3} \mathrm{H}\right]$ thymidine incorporation ( $71 \%$ of control). This increased inhibitory activity after acid treatment is again consistent with the presence of latent TGF- $\beta$ in lung lymph.

TGF- $\beta$ antibodies partially blocked lung lymph induced inhibition of MK cell proliferation (Fig. 2). Acid activated lung lymph $(60 \mu \mathrm{l})$ that had been incubated with TGF- $\beta$ antibodies did not inhibit DNA synthesis of MK cells to the same extent as acid-activated lymph alone. Incorporation of $\left[{ }^{3} \mathrm{H}\right]$ thymidine was increased from $3 \%$ of control to $10 \%$ with $10 \mu \mathrm{g} / \mathrm{ml}$ of antibody and to $25 \%$ with $100 \mu \mathrm{g} / \mathrm{ml}$ of antibody. Nonimmune rabbit IgG did not alter the inhibition. Antibodies to TGF- $\beta$ also blocked activity in hypertensive lymph (data not shown).

Radioreceptor assay. Acid-activated lung lymph from control sheep competed strongly for binding in the radioreceptor assay (Fig. $3 \mathrm{~A}$ ). Approximately $10 \mu \mathrm{l}$ of lymph resulted in $50 \%$ inhibition of ${ }^{125} \mathrm{I}$-TGF- $\beta$ binding (Fig. $3 A$ ). The results were remarkably similar in all control samples tested and similar results were obtained with samples taken from the same animal more than 1 wk apart. No activity could be detected in an untreated lung lymph sample that was assayed immediately after collection (data not shown). Some samples that were frozen before assay showed small but detectable amounts of activity, perhaps reflecting activation of TGF- $\beta$ during storage. Since most samples were frozen before the assays, it was not possible to determine whether any TGF- $\beta$ was active in control lung lymph. Freezing and storage did not alter the amount of total activity detected in acid-treated samples.

As can be seen in Fig. $3 B, 1 \mathrm{ng} / \mathrm{ml}$ of purified TGF- $\beta$

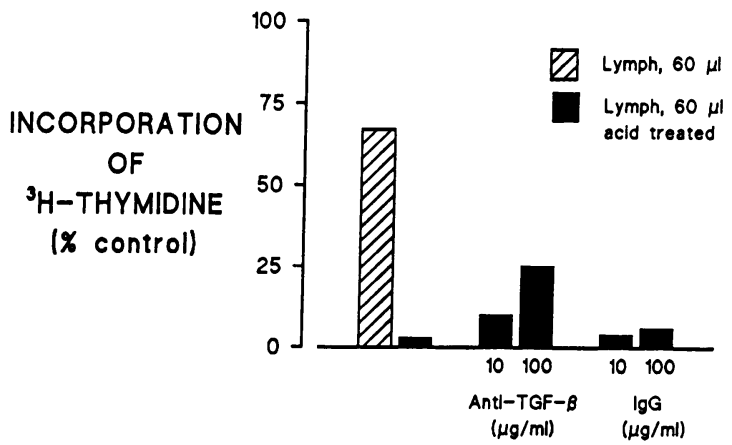

Figure 2. The incorporation of $\left[{ }^{3} \mathrm{H}\right]$ thymidine into MK cells was decreased in the presence of $60 \mu \mathrm{l}$ of untreated lymph. After acid activation this inhibitory effect was markedly increased. Preincubation of lung lymph with TGF- $\beta$ antibodies partially blocked the inhibition. Results are from triplicate wells.


Figure 3. (A) Acid treated lung lymph competed with ${ }^{125}$ I-TGF- $\beta$ in the radioreceptor assay. Inhibition curves from six different samples of control lung lymph are shown. Results are from triplicate wells for each concentration. Approximately $10 \mu \mathrm{l}$ of lung lymph resulted in $50 \%$ inhibition of ${ }^{125}$ I-TGF- $\beta$ binding. ( $B$ ) Porcine platelet-derived TGF- $\beta$ was used to construct a standard curve for the radioreceptor assay. $1 \mathrm{ng}$ of TGF- $\beta$ resulted in $50 \%$ inhibition of binding.

resulted in $50 \%$ inhibition of the binding of ${ }^{125} \mathrm{I}-\mathrm{TGF}-\beta$. Thus the calculated concentration of TGF- $\beta$ in acid-treated control lung lymph was $\sim 100 \mathrm{ng} / \mathrm{ml}$.

\section{"Hypertensive" lung lymph}

Radioreceptor assay. Acid-treated lung lymph collected from sheep during air embolization showed an increase in TGF- $\beta$ competing activity over control lung lymph (Fig. 4). The concentrations of TGF- $\beta$ in lung lymph at baseline and during air embolization are shown (Fig. $4 A$ ) and the concentration was calculated from the volume of lung lymph resulting in $50 \%$ inhibition of specific binding. Lung lymph concentrations of TGF- $\beta$ increased early during embolization (baseline $=77-125 \mathrm{ng} / \mathrm{ml}$; air embolization $=154-333$ ), but by day 5 the concentrations were similar to baseline samples. The concentration of TGF- $\beta$ was lower than baseline in lung lymph collected after day 9 of embolization (27-59 ng/ml). The majority of the TGF- $\beta$ present in hypertensive lymph was latent. Although some active TGF- $\beta$ was present in occasional samples (data not shown), it is not yet possible to determine whether the activity was an artefact of freezing and thawing of the samples or reflects in vivo activation.

The flux of TGF- $\beta$ may be a more accurate reflection of production/release of TGF- $\beta$ in the lung. Flux was calculated by multiplying the concentration of TGF- $\beta$ in lung lymph by its flow rate. There was a marked four- to fivefold increase in 



Figure 4. $(A)$ TGF- $\beta$ in acid treated lung lymph during $12 \mathrm{~d}$ of air embolization. Concentrations were calculated from the radioreceptor assay ( $50 \%$ inhibition $=1 \mathrm{ng}$ of TGF- $\beta$ ). Control animals that did not receive any air embolization are shown at 0 on the $X$ axis. $(B)$ Flux of TGF- $\beta$ from lungs during $12 \mathrm{~d}$ of air embolization (flux $=$ lung lymph concentration of TGF- $\beta$ times flow).

TGF- $\beta$ flux during the first days of embolization which returned to control values by day 7 (Fig. $4 B$ ).

\section{Discussion}

Little is known of the role of TGF- $\beta$ in vivo either under normal or pathological conditions. This study demonstrates that TGF- $\beta$ is a normal constituent of sheep lung lymph and that the levels increase transiently before the development of pulmonary hypertension.

The cellular origin of TGF- $\beta$ in lung lymph is not known. Lung lymph is a filtrate of plasma, with the addition of factors present or produced in the interstitium and vessel walls. Normal plasma does not contain TGF- $\beta$ (13), however it is possible that circulating platelets or inflammatory cells release TGF- $\beta$. A recent study of human epithelial lining fluid has suggested that airway cells, particularly alveolar macrophages, are the source of TGF- $\beta$ detected in normal human epithelial lining fluid $(18,29)$. While it is possible that the airway cells contribute to the level of TGF- $\beta$ in lung lymph, the level is tenfold greater than that found in epithelial lining fluid, suggesting that TGF- $\beta$ is also produced by other cells in the interstitium and/or vascular wall. Endothelial cells (30) and lymphocytes $(31,32)$ have been reported to produce TGF- $\beta$ in vitro and may also contribute to the TGF- $\beta$ in lung lymph. Platelets are a rich source of TGF- $\beta(13,14)$ but they are not present in lung lymph.

The level of TGF- $\beta$ in sheep lung lymph is higher (100 $\mathrm{ng} / \mathrm{ml}$ ) than that required for a maximal response in a variety of in vitro biological assays $(\sim 10 \mathrm{ng} / \mathrm{ml})$. It is possible that the high levels are an artefact of surgery and lymph duct cannulation. However, this seems improbable as control values were consistent and reproducible even in samples collected up to 3 wk after surgery. Recently, high levels of TGF- $\beta$ mRNA have been reported in normal murine lung (33), indicating constitutive production of TGF- $\beta$ in the lung. Whether TGF- $\beta$ is expressed at high levels in the lung of other species is presently not known.

The role of TGF- $\beta$ in the lung, as in other tissues, is not known. TGF- $\beta$ present in interstitial fluid may help maintain normal cellular homeostasis, modulating cellular proliferation and function. TGF- $\beta$ has been implicated in the repair of skin wounds (34) and may have similar functions in lung injury. An interstitial reservoir of latent TGF- $\beta$ in the lung would provide immediate availability of TGF- $\beta$ for tissue repair in areas of injury where platelets are not normally present, and before the recruitment and/or activation of mononuclear cells.

This study has shown an increase in lung lymph TGF- $\beta$ during air embolization before the onset of sustained pulmonary hypertension. In this model, the pulmonary hypertension is accompanied by several well characterized structural changes in the pulmonary arterial bed including an increase in medial thickness secondary to matrix deposition, smooth muscle hypertrophy, and perhaps hyperplasia (22). Signifcantly increased concentrations of elastin peptides in lung lymph have also been demonstrated (35). In culture, TGF- $\beta$ has been shown to both inhibit and stimulate proliferation, depending on culture conditions $(10,11)$. TGF- $\beta$ also causes smooth muscle cell hypertrophy (10) and stimulates elastin production (9). Such findings suggest that TGF- $\beta$ could directly mediate the structural changes of chronic pulmonary hypertension. Further support comes from the work of Sarzani et al., demonstrating increased expression of TGF- $\beta$ mRNA in aortae from rats with systemic hypertension (36).

The transient nature of the increase in TGF- $\beta$ in lung lymph suggests that TGF- $\beta$ may indirectly exert some effects by triggering a cascade of events that lead to remodeling of the pulmonary arteries. This idea is consistent with results found in a hamster bleomycin model of pulmonary fibrosis, where a burst of TGF- $\beta$ mRNA expression was detected at $10 \mathrm{~d}$, while the fibrosis was not present until $21 \mathrm{~d}$ (37). Additionally, studies have shown that TGF- $\beta$ causes a delayed stimulation of fibroblast proliferation in vitro through the induction of c-sis production (38). Similarly, TGF- $\beta$ stimulates c-sis (B chain of platelet-derived growth factor) in human endothelial cells (39). Platelet-derived growth factor is not only a potent smooth muscle cell mitogen (40), but also a vasoconstrictor (41). TGF- $\beta$ also leads to increased production and release of another vasoconstrictor, endothelin (42). Release of such TGF- $\beta$-stimulated vasoconstrictor agents may contribute to the development of sustained pulmonary hypertension. Preliminary studies show that lung lymph from control and air embolized sheep can both stimulate and inhibit proliferation of cultured vascular smooth muscle cells depending on the concentration (43), and suggest the presence of multiple factors that modulate proliferation. The structural changes in chronic pulmonary hypertension are most likely to involve the interaction of several mediators.

The cellular source of TGF- $\beta$ in lung lymph during air embolization is not known and may be multiple. Levels of constitutive production of TGF- $\beta$ may change during the 
pathogenesis of disease as may the contribution from other sources such as inflammatory cells. For example, inflammation has been associated with the development of chronic pulmonary hypertension both in animal models and in human disease (44) and granulocytes may well represent a source of TGF- $\beta$ (45). Platelets are a rich source of TGF- $\beta$ and it is possible that degranulation occurs during air embolization, releasing TGF- $\beta$ into the plasma. The high baseline concentration of TGF- $\beta$ in lung lymph might suggest that an increase is unnecessary to elicit pathogenic effects, but it may be that the vascular wall cannot readily utilize an interstitial pool of TGF- $\beta$ and thus a local source, such as endothelial cells, inflammatory cells, or even the smooth muscle cells themselves must be generated for vascular remodeling to occur. Studies are in progress in our sheep model to determine the cellular origin of TGF- $\beta$ in the lung.

Activation of latent TGF- $\beta$ may be the crucial factor in controlling effects of TGF- $\beta$. Lyons et al. (16) have shown that plasmin can activate TGF- $\beta$, which doubtlessly represents a more physiological mechanism of activation than acidification. Other studies have confirmed the idea that plasmin may be involved in activation using an endothelial cell/pericyte co-culture system (46). It is possible that proteases released in areas of injury may also allow activation of latent TGF- $\beta$ in the lung. The role of proteases in lung injury induced by air embolization has not been extensively studied, however a serine protease has been identified in lung lymph after $4 \mathrm{~h}$ of air embolization (47). Whether this protease could activate TGF- $\beta$ has not been examined. One source of proteases in the lung is the granulocyte and these cells have been linked to the increased microvascular permeability that accompanies air embolization (48). Alternatively, increased production TGF- $\beta$ per se might be linked to activation. Potential mechanisms for TGF- $\beta$ activation need to be further explored.

In summary, we have shown that sheep lung lymph contains high levels of TGF- $\beta$ activity. This activity increases during continuous air embolization before the development of structural remodeling of the pulmonary arteries. The data suggest that TGF- $\beta$ could be involved in the response of the lung to the vascular changes induced by air embolization. Further studies are needed to identify the source of TGF- $\beta$ and mechanisms for its activation.

\section{Acknowledgments}

The authors wish to thank Pam Curtis-Atchley and Mary Aakre for their excellent technical assistance.

This work was supported in part by grants from the National Institutes of Health (HL-02776, RR-05424, CA-42572, HL-19153, and HL-34208).

\section{References}

1. Moses, H. L., E. B. Branum, J. A. Proper, and R. A. Robinson. 1981. Transforming growth factor production by chemically transformed cells. Cancer Res. 41:2842-2848.

2. Roberts, A. B., M. A. Anzano, L. C. Lamb, J. M. Smith, C. A. Frolik, H. Marquardt, G. J. Todaro, and M. B. Sporn. 1982. Isolation from murine sarcoma cells of a new class of transforming growth factors potentiated by epidermal growth factor. Nature (Lond.). 295:417-419.
3. Sporn, M. B., A. B. Roberts, L. M. Wakefield, and B. de Crombrugghe. 1987. Some recent advances in the chemistry and biology of transforming growth factor-beta. J. Cell Biol. 105:1039-1045.

4. Chen, J.-K., H. Hoshi, and W. L. McKeehan. 1987. Transforming growth factor type $\beta$ specifically stimulates synthesis of proteoglycan in human adult arterial smooth muscle cells. Proc. Natl. Acad. Sci. USA. 84:5287-5291.

5. Laiho, M., O. Sakesela, P. A. Andreasen, and J. Keski-Oja. 1986. Enhanced production and extracellular deposition of the endothelialtype plasminogen activator inhibitor in cultured lung fibroblasts by transforming growth factor-beta. J. Cell Biol. 103:2403-2410.

6. Ignotz, R., and J. Massagué. 1986. Transforming growth factorbeta stimulates the expression of fibronectin and collagen and their incorporation into the extracellular matrix. J. Biol. Chem. 261:43374345 .

7. Roberts, A. B., M. B. Sporn, R. K. Assoian, J. M. Smith, N. S. Roche, L. M. Wakefield, U. I. Heine, L. A. Liotta, V. Falanga, J. H. Kehrl, and A. S. Fauci. 1986. Transforming growth factor type-beta: rapid induction of fibrosis and angiogenesis in vivo and stimulation of collagen formation in vitro. Proc. Natl. Acad. Sci. USA. 83:4167-4171.

8. Fine, A., and R. H. Goldstein. 1987. The effect of transforming growth factor $\beta$ on cell proliferation and collagen formation by lung fibroblasts. J. Biol. Chem. 262:3897-3902.

9. Liu, J.-M., and J. M. Davidson. 1988. The elastogenic effect of recombinant transforming growth factor-beta on porcine aortic smooth muscle cells. Biochem. Biophys. Res. Commun. 154:895-901.

10. Owens, G. K., A. T. Geisterfer, Y. W-H. Yang, and A. Komoriya. 1988. Transforming growth factor- $\beta$-induced growth inhibition and cellular hypertrophy in cultured vascular smooth muscle cells. $J$. Cell Biol. 107:771-780.

11. Assoian, R. K. and M. B. Sporn. 1986. Type $\beta$ transforming growth factor in human platelets, release during platelet degranulation and action on vascular smooth muscle cells. J. Cell Biol. 102:12171223.

12. Roberts, A. B., C. A. Frolik, M. A. Anzano, and M. B. Sporn. 1983. Transforming growth factors from neoplastic and nonneoplastic tissues. Fed. Proc. 42:2621-2626.

13. Childs, C. B., J. A. Proper, R. F. Tucker, and H. L. Moses 1982. Serum contains a platelet-derived transforming growth factor. Proc. Natl. Acad. Sci. USA. 79:5312-5316.

14. Assoian, R. K., A. Komoriya, C. A. Meyers, D. M. Miller, and M. B. Sporn. 1983. Transforming growth factor-beta in human platelets. J. Biol. Chem. 258:7155-7160.

15. Lawrence, D. A., R. Pircher, and P. Julien. 1985. Conversion of a high molecular weight latent $\beta$-TGF from chicken embryo fibroblasts into a low molecular weight active $\beta$-TGF under acidic conditions. Biochem. Biophys. Res. Commun. 133:1026-1034.

16. Lyons, R. M., J. Keski-Oja, and H. L. Moses. 1988. Proteolytic activation of latent transforming growth factor- $\beta$ from fibroblast-conditioned medium. J. Cell Biol. 106:1659-1665.

17. Meyrick, B., and L. Reid. 1983. Pulmonary hypertension: anatomic and physiologic correlates. Clin. Chest Med. 4:199-217.

18. Yamauchi, K., Y. Martinet, P. Basset, G. S. Fells, and R. G. Crystal. 1988. High levels of transforming growth factor- $\beta$ are present in the epithelial lining fluid of the normal human lower respiratory tract. Am. Rev. Respir. Dis. 137:1360-1363.

19. Brigham, K. L., R. E. Bowers, and J. Haynes. 1979. Increased vascular permeability caused by Escherichia coli endotoxin. Circ. Res. 45:292-297.

20. Ogletree, M. L., C. J. Begley, G. A. King, and K. L. Brigham. 1986. Influence of steroidal and nonsteroidal anti-inflammatory agents on the accumulation of arachidonic acid metabolites in plasma and lung lymph after endotoxemia in awake sheep. Measurement of prostacyclin and thromboxane metabolites and 12-HETE. Am. Rev. Respir. Dis. 133:55-61.

21. Demling, R. H., C. Lalonde, P. Ryan, D. Zhu, and Y. Liu. 1988. Endotoxemia produces an increase in arterial but not venous lipid peroxides. J. Appl. Physiol. 64:592-598. 
22. Perkett, E. A., K. L. Brigham, and B. Meyrick. 1988. Continuous air embolization into sheep causes sustained pulmonary hypertension and increased pulmonary vasoreactivity. Am. J. Pathol. 123:444454.

23. Staub, N. C., R. D. Bland, K. L. Brigham, R. Demling, A. J. Erdmann, and W. C. Woolverton. 1975. Preparation of chronic lung lymph fistulas in sheep. J. Surg. Res. 19:315-320.

24. Weissman, B. E., and S. A. Aaronson. 1983. Balb and Kirsten murine sarcoma viruses alter growth and differentiation of EGF-dependent BALB/c mouse epidermal keratinocyte lines. Cell. 32:599606.

25. Coffey, R. J., Jr., N. J. Sipes, C. C. Bascom, R. Graves-Deal, C. Y. Pennington, B. E. Weissman, and H. L. Moses. 1988. Growth modulation of mouse keratinocytes by transforming growth factors. Cancer Res. 48:1596-1602.

26. Keski-Oja, J., R. M. Lyons, and H. L. Moses. 1988. Immunodection and modulation of cellular growth with antibodies against native transforming growth factor- $\beta$. Cancer Res. 47:6451-6458.

27. Tucker, R. F., E. L. Branum, G. D. Shipley, R. J. Ryan, and H. L. Moses. 1984. Specific binding to cultured cells of ${ }^{125} \mathrm{I}$-labeled type $\beta$ transforming growth factor from human platelets. Proc. Natl. Acad. Sci. USA. 81:6757-6761.

28. Massagué, J. 1987. Identification of receptors for type- $\beta$ transforming growth factor. Methods Enzymol. 146:174-195.

29. Assoian, R. K., B. E. Fleurdelys, H. C. Stevenson, P. J. Miller, D. K. Madtes, E. W. Raines, R. Ross, and M. B. Sporn. 1987. Expression and secretion of type $\beta$ transforming growth factor by activated human macrophages. Proc. Natl. Acad. Sci. USA. 84:6020-6024.

30. Hannon, R. L., S. Kourembanas, K. C. Flanders, S. J. Rogelj, A. B. Roberts, D. V. Faller, and M. Klagsbrun. 1988. Endothelial cells synthesize basic fibroblast growth factor and transforming growth factor beta. Growth Factors. 1:7-17.

31. Kehrl, J. H., L. M. Wakefield, A. B. Roberts, S. Jakowlew, M. Alvarez-Mon, R. Derynck, M. B. Sporn, and A. S. Fauci. 1986. Production of transforming growth factor $\beta$ by human $T$ lymphocytes and its potential role in the regulation of $\mathrm{T}$ cell growth. J. Exp. Med. 163:1037-1050.

32. Kehrl, J. H., A. B. Roberts, L. M. Wakefield, S. Jakowlew, M. B. Sporn, and A. S. Fauci. 1986. Transforming growth factor $\beta$ is an important immunomodulatory protein for human B lymphocytes. $J$. Immunol. 137:3855-3860.

33. Miller, D. A., A. Lee, R. W. Pelton, E. Y. Chen, H. L. Moses, and $R$. Derynck. 1989. Murine transforming growth factor- $\beta 2 \mathrm{cDNA}$ sequence and expression in adult tissues and embryos. Mol. Endocrinol. 3:1108-1114.

34. Lynch, S. E., R. B. Colvin, and H. N. Antoniades. 1989. Growth factors in wound healing. J. Clin. Invest. 84:640-646.

35. Perkett, E. A., J. M. Davidson, P. Curtis-Atchley, M. L. Sut- cliffe, K. L. Brigham, and B. Meyrick. 1989. Lung lymph elastin concentration is increased in sheep with pulmonary hypertension secondary to air embolization. Am. Rev. Respir. Dis. 139:174a. (Abstr.)

36. Sarzani, R., P. Brecher, and A. V. Chobanian. 1989. Growth factor expression in aorta of normotensive and hypertensive rats. $J$. Clin. Invest. 83:1404-1408.

37. Raghow, R., P. Irish, and A. H. Kang. 1989. Coordinate regulation of transforming growth factor $\beta$ gene expression and cell proliferation in hamster lungs undergoing bleomycin-induced pulmonary fibrosis. J. Clin. Invest. 84:1836-1842.

38. Leof, E. B., J. A. Proper, A. S. Goustin, G. D. Shipley, P. E. DiCorletto, and H. L. Moses. 1986. Induction of c-sis mRNA and activity similar to platelet-derived growth factor by transforming growth factor $\beta$ : a proposed model for indirect mitogenesis involving autocrine activity. Proc. Natl. Acad. Sci. USA. 83:2453-2457.

39. Daniel, T. O., and Z. Fen. 1988. Distinct pathways mediate transcriptional regulation of platelet-derived growth factor $B / c-s i s$ expression. J. Biol. Chem. 263:19815-19820.

40. Ross, R., E. W. Raines, and D. F. Bowen-Pope. 1986. The biology of platelet-derived growth factor. Cell. 46:155-169.

41. Berk, B. C., R. W. Alexander, T. A. Brock, M. A. Gimbrone, Jr., and R. C. Webb. 1986. Vasoconstriction: a new activity for platelet-derived growth factor. Science (Wash. DC). 232:87-90.

42. Kurihara, H., M. Yoshizumi, T. Sugiyama, F. Takaku, M. Yanagisawa, T. Masaki, M. Hamaoki, H. Kato, and Y. Yazaki. 1989. Transforming growth factor- $\beta$ stimulates the expression of endothelin mRNA by vascular endothelial cells. Biochem. Biophys. Res. Commun. 159:1435-1440.

43. Perkett, E. A., R. L. Hoover, K. L. Brigham, and B. Meyrick. 1989. Smooth muscle cell proliferation in vitro is stimulated by lung lymph from sheep with pulmonary hypertension. Am. Rev. Respir. Dis. 139:171a. (Abstr.)

44. Meyrick, B., E. A. Perkett, and K. L. Brigham. 1987. Inflammation and models of chronic pulmonary hypertension. Am. Rev. Respir. Dis. 136:765-767.

45. Grotendorst, G. R., G. Smale, and D. Pencev. 1989. Production of transforming growth factor beta by human peripheral blood monocytes and neutrophils. J. Cell. Physiol. 140:396-402.

46. Sato, Y., and D. B. Rifkin. 1989. Inhibition of endothelial cell movement by pericytes and smooth muscle cells: activation of a latent transforming growth factor- $\beta 1$-like molecule by plasmin during coculture. J. Cell Biol. 109:309-315.

47. Lesser, M., M. R. Flick, B. Kent, and M. Orlowski. 1987. Proteolytic activity in sheep lung lymph as marker of lung capillary injury. Am. Rev. Respir. Dis. 135:643-650.

48. Flick, M. R., A. Perel, and N. C. Staub. 1981. Leukocytes are required for increased lung microvascular permeability after microembolization in sheep. Circ. Res. 48:344-351. 